\title{
An Empirical Study on the Macro Factors Affecting the Income Gap between Industries
}

\author{
Manxue Chen* \\ School of Business \\ Northeast Normal University \\ Changchun, P.R.China, 130117 \\ chenmx839@nenu.edu.cn
}

\author{
Kangyin Lu \\ School of Business \\ Northeast Normal University \\ Changchun, P.R.China, 130117 \\ luky440@ nenu.edu.cn
}

\author{
Fenghua Zou \\ School of Business \\ Northeast Normal University \\ Jilin Police College \\ Changchun, P.R.China, 130117
}

\begin{abstract}
The problem of China's income gap is increasingly serious, especially the problem of income gap between the industry, leading to the economic efficiency, deepening social contradictions, employment problems and other economic and social problems. From the macro perspective, this chapter makes empirical analysis of the causes of the income gap of China's 38 industrial sectors and the effect of various factors on the basis of macro statistical data. The study concluded that the industry characteristics of China's industrial sector wage income gap in the interpretation of the degree of $60 \%$ or more, but with the time passing the impact of industry characteristic reduce gradually.
\end{abstract}

Keywords - industry income gap; macro factors; industry monopoly

\section{INTRODUCTION}

Since the reform and opening up, along with the improvement of the income level of residents, the income gap of residents has been expanding. From 1990 to 2012, the Gini coefficient of income of urban residents industry rose from 0.058 to 0.175 , an increase of nearly 2 times, with an average annual increase of 5.1\%; while the income gap between urban residents only expanded by $38.4 \%$, with an average annual increase of only $1.5 \%$. This means that the expansion of the income gap between the industries is far faster than the speed of the expansion of the income gap between urban residents in China, has become the main driving force of the widening income gap of urban residents. More important, it is different from the gap between urban and rural areas and the regional gap, the administrative monopoly and other unreasonable factors lead to the income gap between the industries is more likely to induce people's unbalanced psychology, thereby endangering social stability.

In the analysis of the reasons for the formation of the income gap between China's industries, many domestic scholars pay attention to the monopoly of the industry. According to the human capital investment theory, Industry human capital stock high, the industry's average labor productivity will be higher, the payment of labor remuneration based on industry labor productivity differences, which is reasonable to explain the formation of the income gap between different industries. In addition, industry productivity is also considered to be an important reason for the impact of industry income gap (Martins, 2004) [1]. Yang Xiuyun etc. (2012) using the SFA method to analyze the relationship between income and efficiency, the results show that the industry efficiency is an important factor to promote the Kuznets curve inflection point in China [2].

In summary, to explore and measure the income gap influencing factors from the macro level between the industry, and further decomposition of the contribution of various factors on the income gap between the industry, which is the key to depict the income gap in China's industries.

\section{MODEL SETTING AND VARIABLE SELECTION}

This paper selects 38 industries (excluding other mining) as the research object, from 2004 to 2012 Chinese Statistical Yearbook and Chinese Labor Statistics Yearbook as the main source of data, in-depth study of various factors affecting the industry income.

The model of this paper takes an example of industry Mincerian wage equation [3]selected by Zhong Ren (2009), and select 5 indexes that impact the income gap between the industries by integrating the previous literature:

$$
Y_{i t}=\alpha_{i t}+\beta_{1} X_{1, i t}+\beta_{2} X_{2, i t}+\beta_{3} X_{3, i t}+\beta_{4} X_{4, i t}+\beta_{5} X_{5, i t}+
$$

In which, the explanatory variables $Y_{i t}$ are the industry average wages; $\alpha_{i t}$ and $\varepsilon_{i t}$ are the constant term and the random disturbance term respectively;

In the explanatory variables, $\mathrm{X}_{1}$ is the degree of monopoly industries, which is measured by the industry's nationalization. $\mathrm{X}_{1}=$ ((industry $\mathrm{i}$ state-owned units employment divides the 
industry employment) + industry i state-owned state holding assets divides total assets of the industry) divides 2 ). $\mathrm{X}_{2}$ is the industry profit per capita, which is a measure of industry profitability characteristics, and $X_{2}=$ the total profit of the industry $\mathrm{i}$ divides the industry $\mathrm{i}$ employment. $\mathrm{X}_{3}$ is the proportion of foreign direct investment, which is to measure the degree of participation in the industry and investment preference of foreign direct investment (FDI), and $\mathrm{X}_{3}=$ industry $\mathrm{i}$ foreign (including Hong Kong and Taiwan) investment assets divide the total assets for the industry. $\mathrm{X}_{4}$ is the industry employment scale, which is used to investigate the employment scale. $\mathrm{X}_{4}=$ industry $\mathrm{i}$ employment divides full sample employment. $\mathrm{X}_{5}$ is the labor productivity, which reflects the industry level of production capacity, and $\mathrm{X}_{5}=$ industry $i$ output divides the industrial industry employment.

\section{LEAST SQUARES REGRESSION ANALYSIS}

In this paper, in using the method of least squares (OLS) regression, at the same time, using robust standard error and White test so as to overcome the existence of different variance due to the cross section data and the limitation of the sample size.

TABLE I.

INDUSTRY’S MINCER WAGE REGRESSION RESULTS

\begin{tabular}{|c|c|c|c|c|c|c|}
\hline $\mathbf{y}$ & Coef. & $\begin{array}{l}\text { Robust } \\
\text { Std.Err. } \\
\end{array}$ & $t$ & $\mathbf{P}>\mathbf{t}$ & [95\% Conf & Interval] \\
\hline $\mathrm{x} 1$ & 24679.35 & 2859.793 & 8.63 & 0.000 & 19053.99 & 30304.7 \\
\hline $\mathrm{x} 2$ & .0655302 & 0.009849 & 6.65 & 0.000 & 0.0461568 & 0.084904 \\
\hline $\mathrm{x} 3$ & 20803.68 & 3318.957 & 6.27 & 0.000 & 14275.13 & 27332.23 \\
\hline $\mathrm{x} 4$ & 91579.38 & 18635.55 & 4.91 & 0.000 & 54922.33 & 128236.4 \\
\hline x5 & .0049027 & 0.000852 & 5.75 & 0.000 & 0.003227 & 0.006579 \\
\hline \multirow[t]{3}{*}{ cons } & -2699.809 & 2070.272 & -1.3 & 0.193 & -6772.137 & 1372.519 \\
\hline & \multicolumn{2}{|c|}{ R-squared } & \multicolumn{4}{|l|}{0.6461} \\
\hline & \multicolumn{2}{|l|}{$\mathrm{F}$} & 44.63 & & $\mathrm{P}$ & 0.000 \\
\hline
\end{tabular}

Note: ${ }^{* * *},{ }^{* *}$, and ${ }^{*}$ respectively stands for the coefficient of $1 \%, 5 \%$, and $10 \%$ level significantly

The regression results can be seen from Table 1 , which is 0.6464 after being adjusted. It suggests that Mincerian wage equation better fit by inspecting value of F. From the estimated coefficient, average income positively affects the industry monopoly significantly, which indicates that the current China high income of monopoly industries phenomenon still exists. This may be because of the monopoly industry by virtue of its monopoly position and barriers to entry. To obtain high profits, and allocate part of the profits to the monopoly industry employment through subsidies, subsidies and welfare projects thus, thus, leading the income level of the monopoly industry employment is relatively high (Hou Fengyun and Yin Shubiao, 2008) [4]. Industry profits per capita regression coefficient by the $1 \%$ significance level test, because the industry profit per capita can measure an industry's profitability level, the regression results show industry profitability is stronger, the average income of the industry's employment level is higher. The proportion of foreign direct investment to the industry average income level has significant positive effects, Zhong Ren (2009) thinks this is due to foreign investment arising from the "overflow effect", which will make the industrial output increase and accompanied by the industry to raise the level of income [3]. Industry employment scale index is in the $1 \%$ significant level of positive effects and the industry average wage, which shows that the larger the industry employment scale, the higher the average wage of the industry. Full labor productivity has a significant positive effect on the industry average income, which shows that the industry with high labor productivity and its production capacity is relatively strong, and the industry workers are more likely to obtain a higher efficiency wage.

\section{RANIS-FEI MODEL}

This paper uses Zhong Ren and Zhou Yunbo (2009) - the study of Ranis-Fei Model for reference, to analyze the industry characteristics on the income gap between the industry contribution degrees [5]. Decomposition model:

$G=\varphi_{1} R_{1} G_{1}+\varphi_{2} R_{2} G_{2}+\cdots+\varphi_{i} R_{i} G_{i} \cdots+\Delta(i=1,2 \cdots)(2)$

In which, $\varphi_{\mathrm{i}}$ is the industry characteristics of the income. $\varphi_{i}=\alpha_{i} \frac{I_{i}}{Y}$, in which, $\alpha_{i}$ is the regression coefficient of industry $\mathrm{i}$ characteristics industry, $\mathrm{I}_{\mathrm{i}}$ is the wage equation of the average for the industry $i$, the feature in $\mathrm{Y}$ is the average value of industry income. $R_{i}$ is the correlation coefficient in $i$ and the characteristics of the industry revenue, namely the characteristics of income correlation, it can reflect the correlation between the characteristics of industry and industry of middle income. $G_{i}$ is the Gini coefficient is the industry $i$ characteristics, which reflects the distribution characteristics of the industry. $\Delta$ is the weighted grade error. Through the decomposition, we can obtain that: $\varphi_{i} R_{i} G_{i}$ is the contribution of the characteristics of the industry i. $\sum_{i} \varphi_{i} R_{i} G_{i}$ is the total contribution to the industry characteristics. 
TABLE II. THE INCOME GAP BETWEEN THE INDUSTRY RANIS-FEI MODEL RESULTS

\begin{tabular}{|c|c|c|c|c|c|c|}
\hline Year & & $\begin{array}{l}\text { Industry } \\
\text { monopoly } \\
\text { degree }\end{array}$ & $\begin{array}{l}\text { Industry per } \\
\text { capita profit }\end{array}$ & $\begin{array}{l}\text { Foreign direct } \\
\text { investment ratio }\end{array}$ & $\begin{array}{l}\text { Industry } \\
\text { employment } \\
\text { scale }\end{array}$ & $\begin{array}{l}\text { Total labor } \\
\text { productivity }\end{array}$ \\
\hline \multirow{7}{*}{2003} & Feature weight gains & 0.7658 & 0.1161 & 0.4139 & 0.1840 & 0.1463 \\
\hline & Characteristic income correlation coefficient & 0.6240 & 0.7470 & -0.3460 & 0.0500 & 0.5450 \\
\hline & Characteristic Gini coefficient & 0.3413 & 0.4371 & 0.3920 & 0.4451 & 0.3020 \\
\hline & Industry characteristic contribution & 0.1631 & 0.0379 & -0.0561 & 0.0041 & 0.0241 \\
\hline & Total contribution of industry characteristics & 0.1730 & & & & \\
\hline & Industry Gini coefficient & 0.1661 & & & & \\
\hline & Industry characteristic contribution ratio (\%) & 98.17 & 22.83 & -33.80 & 2.47 & 14.50 \\
\hline \multirow{7}{*}{2007} & Feature weight gains & 0.3086 & 0.2185 & 0.2861 & 0.1083 & 0.2269 \\
\hline & Characteristic income correlation coefficient & 0.8210 & 0.6800 & -0.4910 & 0.1060 & 0.3070 \\
\hline & Characteristic Gini coefficient & 0.4553 & 0.4202 & 0.3217 & 0.4374 & 0.3232 \\
\hline & Industry characteristic contribution & 0.1154 & 0.0624 & -0.0452 & 0.0050 & 0.0225 \\
\hline & Total contribution of industry characteristics & 0.1602 & & & & \\
\hline & Industry Gini coefficient & 0.1704 & & & & \\
\hline & Industry characteristic contribution ratio (\%) & 67.72 & 36.65 & -26.52 & 2.95 & 13.21 \\
\hline \multirow{7}{*}{2011} & Feature weight gains & 0.1577 & 0.2497 & 0.1439 & 0.0626 & 0.2419 \\
\hline & Characteristic income correlation coefficient & 0.8090 & 0.4740 & -0.4850 & 0.1100 & 0.2440 \\
\hline & Characteristic Gini coefficient & 0.4968 & 0.3431 & 0.3200 & 0.4567 & 0.3084 \\
\hline & Industry characteristic contribution & 0.0634 & 0.0406 & -0.0223 & 0.0031 & 0.0182 \\
\hline & Total contribution of industry characteristics & 0.1030 & & & & \\
\hline & Industry Gini coefficient & 0.1509 & & & & \\
\hline & Industry characteristic contribution ratio (\%) & 42.02 & 26.92 & -14.80 & 2.09 & 12.06 \\
\hline
\end{tabular}

Table 2 shows the representative industry income gap year Ranis -Fei model results. Seen from the chart, we can explain the extent of 5 industry characteristics on the income gap between the industries. In addition to the proportion of foreign direct investment and other 4 industry characteristics of the industry income gap, which is positive, the industry monopoly has the largest contribution, which is more than $40 \%$. The contribution of industry per capita profit is the second, labor productivity contribution is the third, and the contribution of employment scale is smaller and is below 3\%. It is worth noting that the proportion of foreign direct investment to the average wage industry's contribution is negative. $\mathrm{Yu}$ Liangchun and Wang Meichen (2014) believe that this is due to industry labor intensive and strong competition in the manufacturing industry. The degree of opening to the outside world and the foreign direct investment is relatively high, whose constant accumulation of foreign direct investment produces "competition effect" and "internal spillover effect", which improves the industry's average income level, but also to narrow the income gap with the monopoly of the industry [6]. Therefore, the income gap between the industries can be alleviated by increasing the proportion of foreign direct investment, and promoting the diversification of investment main subject.
From the point view of the dynamic change of the characteristics of the industry contribution to the income gap between the industries, the 5 industry characteristics have a large explanation extent to the industry income gap, which is basically in more than $60 \%$. However, from the annual change of view, explanation extent decreases year by year, from $99.97 \%$ in 2011 to $68.28 \%$ in 2003. From the perspective of industry monopoly, its contribution to the income gap between the industries is declining year by year, which can be illustrated by the monopoly industry income inequality situation eased. The proportion of foreign direct investment on the income gap between the negative effects gradually weakened, which shows that foreign direct investment proportion for the income gap between the relief of decline situation and the industry profit per capita, employment scale and labor productivity, although the dynamic contribution to the industry income gap fluctuates, they basically did not change.

\section{CONCLUSION}

Analyze the causes of China's industry income gap and the contribution of the various factors by using the macro statistics and the least square method and the Ranis-Fei model empirical. The study found that the industry characteristics of China's industrial sector wage income gap of the degree of 
interpretation in more than $60 \%$, but the impact of industry characteristics is gradually reduced over time. Among them, the interpretation of the gap between the monopoly factors is also decreasing year by year. China should break the administrative monopoly, improve the income distribution pattern and further narrow the income gap between the industries.

\section{REFERENCE}

[1] Martins P S. Industry Wage Premia: Evidence from the Wage Distribution [J]. Economics Letters, 2004 (83): 157-163.

[2] Yang Xiuyun, Zhu Yining, Zhang Min. Industry efficiency and industry income gap: Based on empirical analysis of panel data SFA model of the typical provinces and cities in China [J]. economic management, 2012 (10): 41-50.(In Chinese)

[3] Ren Zhong. China's industry wage gap measurement and decomposition analysis [J]. Journal of Central University of Finance and Economics, 2009,01:66-71. (In Chinese)

[4] Hou Fengyun, Yi Shubiao. Research on the relationship between administrative monopoly and industry income gap: Based on panel data analysis of industry segments [J]. labor economic review, 2008,00:124-136. (In Chinese)

[5] Ren Zhong, Zhou Yunbo. How much of an impact on the income gap between the industry monopoly in China? [J]. Economic Theory and Economic Management, 2009, 04: 25-30. (In Chinese)

[6] Yu Liangchun, Wang Meichen. Empirical Analysis of the Influence of Monopoly on the Income Gap [J]. Research on economics and management, 2014, 07: 23-33. (In Chinese) 